\title{
A Study on NGO-Donor Relations in Basic Education Sector: Case of Pakistan
}

\author{
${ }^{1}$ Warda Gul, ${ }^{2}$ Kong FanBin \\ ${ }^{12}$ School of Government, Nanjing University, P.R. China \\ Corresponding Author's Email: wardagulh@hotmail.com
}

\begin{abstract}
NGOs gained the importance in the last decades all over the world and the same is true with the case of Pakistan. NGOs are participating in the education sector. This paper studies the involvement of NGOs in the basic education sector, being dependent on the foreign donor agencies. NGOs have to follow the agenda of donors that can create tension with the government. This paper applies qualitative research methodology to study the relationships between donors and NGOs. The findings of this study show that donors are mostly following market-based approach and neo-liberal agenda that results in inequalities for people. Therefore, to perform their duty rightly, NGOs should look for sustainable sources of finances.
\end{abstract}

Key words: NGOs, International Donors, Government, Education, Pakistan

\section{INTRODUCTION}

Pakistan is a country located in South Asia with a population of approximately 190 Million (Pakistan Federal Bureau of Statistics, 2014). The formal education structure of Pakistan is a 10-2-4-2 meaning that 10 Years of Secondary Education, two years of higher secondary education, four years of University professional or degree education and two years of Post Graduate Education (Ministry of Education, Pakistan, 2014). In last the decades, NGOs have become a stakeholder in the education sector in Pakistan though their role is not too much clearly outlined in any policy document of the government of Pakistan. However, right after government permission on legal operation in Pakistan, they have started to play an important role in the education sector and have made a notable contribution. This thesis proposes to explore the role of NGOs in the education sector of Pakistan, in designing and implementation of educational policy for Basic Education in the case of Punjab province of Pakistan (UNDP, 1996).

It has been found in studies that NGOs are dependent upon foreign donors for their activities in Pakistan. The donor agencies have their own priorities and agendas and there many cases where they impose their agenda on NGOs to follow. A major example is market based approach and neo-liberal agenda of International donors (Green, 1999).

Because of this dependence on foreign donors, NGOs have to follow the agenda given by donors that will eventually result in some tensions between NGOs and the governments. Government opposes any such agendas that are being imposed by some foreign organization, especially the ones which threatens the sovereignty of the state (Giroux, 2009). This tension creates a situation of a rift between NGOs and government. This study has been conducted to understand the nature of the relations between NGOs and their donors.

\section{LITERATURE REVIEW}

During past decades, there was an increased interest in education from international organizations including the World Bank and the UN. Both organizations have initiated doctrines for Education. Since 1970's World Bank has been committed to a doctrine based on the dominance of market forces and education has also been seen as a form of developing 'human capital' that will be capable of generating high returns of economic growth (Shultz, 1993).

Globally, two main doctrines apparently seem to be used as a guiding source for the provision of education. One is Human Capital and market driven approach initiated and adopted by the World Bank and Human Rights Approach by United Nations (Silova, 2004). World Bank is considered the largest organization allocating resources for education in the world (Ilon, 2002).

Markets have promoted inequities in education. Though the World Bank and the IMF seem to promote 'equality' in their approach, the reality is that their approach has worsened equalities in education. Markets exacerbate existing inequalities (Ball, 1993; Hill 2003; Seddon, 1997; Klees, 2010). For 


\section{Warda Gul, Kong FanBin \\ A study on NGO-Donor relations in basic education sector, case of Pakistan}

example, school systems in Australia and the USA radicalizing social class patterns of inequality have increased due to market wise school systems (Hill, 2003). This is because the poor cannot afford the high tuition fees demanded by certain schools (Ball et. al, 2010; Hill et. al, 2009; Seddon, 1997; Shah, 2005). As Hill, et al (2008) notes "Increasing the role of the private sector (including for-profit) organizations at primary, secondary and tertiary levels creates unequal access to schooling based on social class, despite compensatory measures, such as subsidies, intended to limit the stratifying effects of capitalization."

Since the end of the 1980s, the educational systems in a number of countries around the world have been submitted to an unceasing flow of reforms (Hitchcock, 1995). The transformation towards neoliberalism involves both re-structuring of relations between the economic, political and social domains (including the commoditization and marketization of fields including education - it becomes subject to the economic logic of the market), and the 're-scaling' of relations between the different levels of social, global, regional (e.g. the European Union), national, and local life (Fairclough, 2006).

Economic decline in Pakistan, as elsewhere in other parts of Asia, compelled national governments to borrow heavily from international banks such as the World Bank and the IMF that resulted in many governments in Asia embracing market-oriented policies due to conditionality attached to loans. A sharp economic decline was experienced in many parts of Asia in the 1970s and 1980s (Thompson, 1997).

\section{RESEARCH OBJECTIVE AND METHODOLOGY}

Table 1: NGOs included in the study

\begin{tabular}{|c|c|c|}
\hline & Name & Focus and Scope \\
\hline 1 & AAA & $\begin{array}{l}\text { - Campaigning and advocacy. Works with local and national NGOs to campaign and } \\
\text { advocate for policy changes and increased accountability of service providers. } \\
\text { - Supports vulnerable children in community schools. } \\
\text { Works through a national NGO which supports community schools. }\end{array}$ \\
\hline 2 & BBB & $\begin{array}{l}\text { - Empowers rural communities by providing them with non-formal education. It } \\
\text { promotes literacy in rural communities especially among women and children. }\end{array}$ \\
\hline 3 & CCC & $\begin{array}{l}\text { - Supports children's rights in schools. It focuses on child protection and } \\
\text { participation. }\end{array}$ \\
\hline 4 & DDD & $\begin{array}{l}\text { - Advocates for policies and programs that support the education of girls and } \\
\text { women. } \\
\text { Advocates for the removal of cultural practices that impinge on female education. } \\
\text { - Supports the disadvantaged and vulnerable students by paying school fees for } \\
\text { them especially girls and women. } \\
\text { - Infrastructural development in schools, for example, building girls' hostels. } \\
\text { - Textbook provision in schools. }\end{array}$ \\
\hline 5 & EEE & $\begin{array}{l}\text { - Provides assistance to vulnerable families so that they can educate their children. } \\
\text { - Rehabilitation of public schools to transform them into "Child Friendly Schools" } \\
\text { (i.e., improving the school environment, making it conducive for learning for } \\
\text { children). }\end{array}$ \\
\hline 6 & FFF & $\begin{array}{l}\text { - Supports child rights' clubs in schools by working through local and national NGOs. } \\
\text { - Monitoring and tracking the education budget expenditure by working in } \\
\text { partnership with local and national NGOs. }\end{array}$ \\
\hline 7 & GGG & - Supports vulnerable children in community schools. \\
\hline 8 & $\mathrm{HHH}$ & $\begin{array}{l}\text { - Lobbying and advocacy aimed at ensuring that the achievement of EFA and MDGs } \\
\text { goals on education by } 2015 \text {. } \\
\text { - Monitoring and tracking the education budget expenditure }\end{array}$ \\
\hline
\end{tabular}




\section{Warda Gul, Kong FanBin \\ A study on NGO-Donor relations in basic education sector, case of Pakistan}

This paper aims to investigate NGOs-Donor relationships in Pakistan. Due to the importance of donor agencies for NGOs and role of NGOs in the basic education sector of Pakistan, the study will contribute significantly to the body of knowledge in the field.

For this study, the researcher has applied an instrumental case study approach. It comes up with multiple data collection methods in order to have a grip on the complexity of the case and looks for multiple perspectives. For this purpose, focus groups, interviews, observation and document review was applied to collect the data on roles of NGOs in education sector of Pakistan.

As per Stake (1995: ix) "A case study is the study of the particularity and complexity of a single case, coming to understand its activity within relevant circumstances" (Stake, 1995). According to Creswell (2007), a case study involves the study of an issue explored through one or more cases within a bounded system (i.e., a setting, a context) (Creswell, 2007). For this study, a sample of 8 NGOs was selected using purposive sampling. Table 10 below includes 8 NGOs included for this study. Names have been coded for purpose of anonymity.

\section{DISCUSSION OF THE FINDINGS}

The interviews expressed and revealed that International NGOs work through their national or local partner NGOs in Pakistan to achieve their objectives including advocacy. The findings from the interview with NGO officials are as follows:

"Being an international NGO, we raise voice through our partners in Pakistan that are the local organizations. Otherwise, we only issue general statements such as "The government should rectify the educational policy or bring some bill for such ratification." If we talk more, we may be told by the government or other stakeholders that we are foreigners and we have to be in some limits" (International NGO Official No. 8, 2014). The representatives from Donor Agencies who were interviewed for this research study were of the view that NGOs are important partners for them in education development in Pakistan.

Donors think about NGOs to be flexible and efficient organizations. From NGOs included in this case study, it has been observed that:

AAA provides necessary help and support to the children studying in community schools and is being funded by the Australian Aid; their program intends to help more children to be enrolled in schools.

BBB gets funded by a wide range of donors as mentioned in the table and they work to protect Children's right that also includes education as a basic human right.

CCC is also being funded by Australian Aid working in local communities to provide the financial help to deprived and vulnerable families to empower them enough to send their children to school.

DDD is also working for the protection of children rights, particularly, in schools and is being funded by "Save the Children" focusing on child right and protection.

EEE is providing technical skill training in rural communities. Programs are funded by UNESCO and the focus is on the improvement of literacy and technical skills.

FFF is also supporting vulnerable children studying in basic education schools; one of its sources is USAID who tend to fund NGOs to help vulnerable children to get an education in their own communities.

NGOs like GGG and $\mathrm{HHH}$ are being funded by Irish and Netherlands aid to play advocacy roles for support of EFA goals.

It was observed earlier as well that GGG and $\mathrm{HHH}$ work for advocacy and lobbying to ensure attainment of EFA goals through these efforts. Here, it was also found from the document review that Government of Pakistan depends on international support to undertake its development and other projects. In many instances, it has been observed that international donors can provide significant proportion of the education budget.

It has been observed that NGOs face different problems including lack of funds, less number of staff, duplication of efforts by other NGOs. Most of NGOs working in Pakistan are dependent on donors for funding from external donor agencies for their operations as they lack their own resources. Most of the donors for NGOs include international NGOs and other donor agencies. The observations and findings of this study show that donors whether external or internal prefer and like to work with NGOs. In donors' 


\section{Warda Gul, Kong FanBin \\ A study on NGO-Donor relations in basic education sector, case of Pakistan}

opinion, NGOs are efficient, and they are less bureaucratic in nature and can help poor masses at the very basic and grass root level. Donors regard and treat NGOs as their important partners in achieving the goals and objectives of EFA in the education sector. While observing the fact that due to various reasons, the government is unable to or lacks the capability to perform and they started depending on NGOs for the implementation of their programs. NGOs have the capabilities to mobilize the local communities and masses due to their reach to remote and rural areas where the population is denser.

\section{CONCLUSION AND RECOMMENDATIONS}

It is recommended that in order to be self-sufficient, NGOs have found out different ways to decrease the dependence on foreign aid for their programs and try to attain sustainability so that they do not have to follow the agenda of their donors that creates problems in their relationships with the government. The primary reason is that it is the government who controls all the policies and formulates rules and regulations for all the sectors in the country and government cannot bear any interference by foreign agencies for the imposition of their agenda. Therefore, such NGOs that are dependent on foreign donors will be having problems by the government. NGOs which can generate their own sources by themselves can only work peacefully.

\section{REFERENCES}

- Federal Bureau of Statistics Reports, Government of Islamic Republic of Pakistan (2014).

- Ministry of Education. National Annual Work Plan and Budget 2007. Government of Pakistan (2014) http://www.moe.gov.pk/

- Government of Islamic Republic of Pakistan-UNDP. Prospects for sustainable Human Development in Pakistan: More choices for Our People, (1996):90-92. UNDP.

- Green, A. Education and Globalization in Europe and East Asia: convergent and divergent trends [J]. Journal of Education policy, (1999):14(1), 55-71.

- Giroux, H.A. Youth, and the Leasing of Higher Education in Dave Hill and Ravi Kumar, Global Neoliberalism and Education and its Consequences [M], (2009):30-53. New York: Routledge.

- Shultz, T. Returns to Women's Education, in E. Kingand A. Hill (ed): Women's Education in Developing Countries: Barriers, Benefits and Policies, Baltimore: (1993) Hopkins University Press.

- Silova, I. Adopting the language of the new allies. In G. Steiner-Khamsi (Ed.), The Global Politics of Educational Borrowing and Lending (2004):75-87, New York: Teachers College Press.

- Ilon. L, The Growing Market for NGO Influence [J]. Current Issues in Comparative Education, (2008) vol. 10:16-21.

- Ball, S. J., and Exley, S. 'Making policy with 'good ideas': policy networks and the intellectuals of New Labor. [J] Journal of Education Policy, (2010), 25(2):151 -169.

- Hill, D., and Kumar, R. Neoliberalism and Its Impacts in Dave Hill and Ravi Kumar [M], Global Neoliberalism and Education and its Consequences, (2009):12-29. New York: Routledge

- Seddon, T. Markets and the English: rethinking educational restructuring as Institutional design [J]. British Journal of Sociology of Education, (1997), 18(2):165-186.

- Shah, A. Non-governmental Organizations on Development Issues [J]. Global Issues (2005) Available on-line: http://www.globalissues.org/article/25/non-governmental-organisations-on development-issues.

- Hitchcock, G. and Hughes, D. Research and the Teacher (second edition) (1995). London: Routledge.

- Fairclough, N. Language and Globalization. London (2006): Routledge.

- Thompson, C. Economic Policy Toward Africa [J]. Foreign Policy in Focus, (1997):2(23), abstract.

- Stake, R. The Art of Case Study Research [M]. California (1995): Sage publications Ltd, Inc.

- Creswell, J. W. Qualitative inquiry and research design [M] Choosing among five approaches (2007) (2nd ed.). London: SAGE Publications 